\title{
Temporary propping at Crossrail Paddington station
}

\section{Paul Chambers MEng}

Graduate Engineer, Skanska UK, Rickmansworth, UK (corresponding author: w.p.chambers@outlook.com)

Charles Augarde BSc, MSc, DPhil, CEng, FICE

Professor, School of Engineering and Computing Sciences, Durham University, Durham, UK
Sam Reed MEng, CEng, MICE

Construction Manager, Skanska UK, Rickmansworth, UK

Adrian Dobbins BSC, CEng, MICE

Engineering Manager, Skanska UK, Rickmansworth, UK

The construction of Crossrail Paddington station in London (between 2011 and 2018) required a large temporary propping system, which contained one of the most comprehensive monitoring schemes to date. This paper explores the design and operation of this system through the analysis of a data set collected during the construction period and the numerical modelling undertaken at Durham University. The effects of temperature variation on the partially exposed propping system are quantified, as well as the impact of events in the construction sequence including slab casting, adjacent prop removal and excavation. Several lessons were learned during the construction, in terms of prop installation and removal and the management of the monitoring system. These are discussed for the benefit of future projects using temporary propping and monitoring schemes. The findings from this research have led to a greater understanding of the behaviour of propping systems under different environmental conditions, and may therefore lead to more efficient and safer designs in the future.

\section{Notation}

A cross-sectional area of the prop

$E \quad$ Young's modulus of the prop material

$E_{50} \quad$ secant stiffness

$E_{\text {oed }} \quad$ odeometer stiffness

$E_{\text {ur }} \quad$ un-/reloading stiffness

$G_{0} \quad$ reference shear modulus

$I_{\mathrm{p}} \quad$ plasticity index

$K_{\text {Onc }} \quad$ normally consolidated in situ earth pressure

$P_{\text {ref }} \quad$ reference pressure

$p_{\mathrm{o}}^{\prime} \quad$ confining pressure

$R_{\mathrm{OC}} \quad$ overconsolidation ratio

$S_{\mathrm{u}} \quad$ shear strength

$S_{\text {uinc }} \quad$ incremental shear strength

$S_{\text {uref }}$ shear strength reference

$\alpha \quad$ thermal coefficient of the prop material

$\beta \quad$ system stiffness

$\gamma \quad$ unit weight

$\gamma_{0 \cdot 7}$ shear strain at $0 \cdot 7 G_{0}$

$\Delta P \quad$ change in thermal load

$\delta T \quad$ change in temperature

$v_{\text {ur }} \quad$ un-/reloading loading Poisson's ratio

\section{Introduction}

Crossrail is a $£ 14 \cdot 8$ billion underground rail project running from Reading and Heathrow to the west of London to Shenfield and Abbey Wood to the east. Ten new stations are being constructed as part of the project, of which the station at Paddington is unique in terms of construction method. The station is constructed inside a single 'box' bounded by $1 \mathrm{~m}$ thick diaphragm walls, the construction of which was completed in 2014. The box is $260 \mathrm{~m}$ long, $25 \mathrm{~m}$ wide and $23 \mathrm{~m}$ deep and was built using a top-down method with temporary shoring and permanent slabs providing propping to the walls. The site is located close to several surface structures, including the Grade 1-listed MacMillan House and the 16-storey 20 Eastbourne Terrace. As a result, deformation control during construction was of extreme importance to the client. To this end, the principal contractor (Costain-Skanska Joint Venture (CJSV)) employed a rigorous monitoring system from which a valuable set of data was obtained.

It is widely accepted that greater understanding of the underlying behaviour of propping systems for large excavations, and their response to variables such as temperature and construction sequence, is needed to permit more economic designs. It may also lead to contractors being able to work in a safer and more efficient manner. Poor understanding of temporary works for large excavations can have catastrophic results. In 2012 the New Civil Engineer magazine considered the Nicoll Highway collapse in Singapore to be the 'greatest civil engineering disaster of the last decade' (Hansford, 2012), highlighting some of the failings of this project as the incorrect choice and use of soil constitutive models in finite-element analyses (FEAs), the poor design of connections in the propping system and the omission of some structural elements of temporary works (Browning, 2012).

To develop improved designs for propping schemes for large excavations, there must be a culture of evaluating the present state of affairs and sharing experience gained from existing projects, both successful and unsuccessful. This is part of the philosophy 
behind the Construction Industry Research and Information Association (Ciria) design guide Ciria C580, Embedded Retaining Walls - Guidance for Economic Design (Gaba et al., 2003). A consultation workshop for the review of C580 in May 2014 found that many industry professionals would like to see more case studies that compare design predictions with measurements during the construction phase (Ciria, 2014). The contractor at Paddington had considerable experience with the propping of deep excavations from projects such as the Channel Tunnel rail link (CTRL) and the Crossrail Royal Oak portal, and wished to consolidate this knowledge base along with that gained at Paddington for future contracts.

The works at Paddington involved one of the largest temporary propping schemes of recent years, and the monitoring system employed during the works appears to have been more comprehensive than any to date. The aim of this paper is to present selected conclusions drawn from the analysis of a large data set obtained from this monitoring campaign and the numerical modelling undertaken at Durham University during the final year of author Paul Chambers' MEng studies. Four areas are focused on: $(a)$ the effects of temperature variation on the propping system, (b) the variation in prop loads with events in the construction process and their sequence, $(c)$ the effect of prestressing the props and $(d)$ the behaviour of the props in the corner of the excavation. With upcoming projects such as High Speed 2 and Thames Tideway using the technology considered in this research, the update of $\mathrm{C} 580$ becomes quite timely (Ciria, 2014), as does the presentation of recent findings from monitoring data.

\section{Previous research in open excavation monitoring}

There are several previous studies of large propped excavations in the UK (mainly London), in which it is clear from the monitoring data that a degree of overconservatism exists in design procedures. Loveridge (2001) used vibrating wire strain gauges and thermistors to analyse the effect of temperature variation on an exposed propping system monitored as part of the CTRL works and found that the prop loads with 'moderately conservative' design were up to twice the corresponding measured loads, a finding independent of the number of props and dewatering schemes. This indicated significant inefficiencies and a lack of understanding of the soil-structure interaction. In 2012, an investigation into the propping system at the Crossrail Royal Oak portal analysed load data from nine props (Ivanova, 2012). This work found that thermal effects accounted for up to $30 \%$ of the load measured. Some attempts were also made to quantify the effects of the casting of the base slab on the prop loadings, and, again, the loads measured on site were well below those expected from the design. This was largely attributed to an overestimation of thermal loads.

These previous studies indicate that design assessments of the effects of temperature, system restraint and construction sequence on propped deep excavations could be overconservative, a finding that is backed up by the data obtained at Paddington.

Considerable research into the physics that governs the behaviour of propped retaining walls has been undertaken over the last half century. In the 2001 Perspective Lecture for the International Conference on Soil Mechanics and Geotechnical Engineering (Simpson and Powrie, 2001), the authors expressed some concern at the 'considerable assumptions' required for two-dimensional (2D) FEA. They also noted that there is still a 'considerable debate' over how earth pressures are distributed. They state that the installation of a retaining wall might cause a drop in the lateral earth pressure coefficient of $10-20 \%$. It is this lateral earth pressure that has the dominant effect on the geotechnical load in propping systems. Furthermore, the authors state that prestressing props or anchors can lead to higher wall bending moments. This implies that there is an optimum level of prestressing, beyond which it is detrimental to the overall system. In an earlier work, Fourie and Potts (1985) found that prop forces will increase with both the in situ lateral earth pressure coefficient $K_{0}$ and the wall stiffness. Simic and French (1998) observed that temporary propping is costly in terms of both time and money and provides a risk to site operatives during installation and removal. It is therefore 'considerably advantageous' to minimise the number of props in a scheme.

Monitoring of construction schemes and existing structures has provided significant knowledge in this field of research. In a study of three different basement excavations, Marchand (1997) suggests that predicting ground movements is difficult due to the range of soil stiffnesses that can be encountered over a relatively small area. In the investigation of Stothard Place in London, it was found that surfaces not in direct sunlight were near ambient air temperature, despite a peak prop surface temperature of $480^{\circ} \mathrm{C}$. On a similar note, in the investigation of temporary propping at Canada Water, Powrie and Batten (2000) reported that the lower level of props had a higher average temperature than the upper level, indicating some degree of thermal damping. Marchand (1997) found that during the winter the raked props in the corner of the excavation recorded no load, which was attributed as 'probably due to corner effects'. Marchand (1997) also suggested that prestress 'dominates' prop behaviour because prestress does not permit the soil to displace and mobilise its maximum support. This finding is echoed by Stroud et al. (1994), who concluded that across all of the sites investigated, prop loads were almost always lower than the design values. This is attributed to an underestimation of short-term soil strength, inaccurate assessment of soil stiffness and assumptions in numerical models.

The effect of temperature variation in a propping system is largely governed by the degree of restraint in the system. The degree of restraint is expressed as a percentage and quantifies the ability of structural members to expand as they get warmer. If the system is totally free to expand, the degree of restraint will be $0 \%$. 
However, if the system cannot expand at all, then it is $100 \%$ restrained. This level of restraint in a system is affected by the stiffness of the retained soil and the connections between the prop, the wall and the soil mass. Gaba et al. (2003) suggested a value of $70 \%$ for a stiff wall in stiff soil and $50 \%$ for a stiff wall in weak soil. Richards et al. (2007) found that the degree of restraint varied between $34 \%$ and $47 \%$ in an investigation of a car park construction in Mayfair, London. In a paper in Géotechnique, Powrie and Batten (2000) found that a value of $50 \%$ would have been more appropriate for the construction of the Canada Water station. Skanska's internal research on the Royal Oak portal presented the same conclusion (Ivanova, 2012). In the investigation of another Mayfair car park (Richards et al., 1999), it was found that prop loads in the corners of the excavation were lower than those near the middle. This was again attributed to 'corner effects'. It appears that the term 'corner effects' has been used in a number of cases as a blanket term for lower than expected prop loads near the corners of an excavation. However, none of the papers reviewed as part of this project go into any great detail as to what corner effects actually are.

Several papers present the results of investigations of retaining walls and propping systems using numerical modelling. Powrie and Batten (2000) compared the measurements taken from construction with those from a FEA using the software Crisp. The authors chose to use a linear elastic/perfectly plastic (Mohr-Coulomb) constitutive model for the soil. This does not model the inherent non-linearity of soil but was justified based on an earlier paper by Burland and Kalra (1986). The slab/wall interactions were modelled as pinned joints, based on the earlier findings of Powrie and Li (1991). Following a parametric study, the authors reported that soil stiffness has the largest effect on wall displacements. Gourvenec et al. (2002) compared displacements found at a wall retained by a berm in two and three dimensions to explore the effect of the assumption that a $2 \mathrm{D}$ section will provide an accurate representation of the system. The paper states that horizontal ground movement during wall installation is reduced by $83 \%$ when modelling in three dimensions. In the paper of Powrie and Li (1991), the effect of varying soil, wall and prop stiffnesses, along with the pre-excavation earth pressure coefficient, was explored. The paper suggests that the bending moments in the walls are mainly dominated by the in situ lateral earth pressure. Furthermore, it reports that small variations in stress distributions can cause comparatively large changes in the prop load. A key theme across all of the papers discussing numerical modelling that were reviewed as part of this project is the importance of stating clearly the assumptions used in an analysis.

\section{Site conditions and monitoring at Paddington}

\section{Ground conditions}

The underlying geology at Paddington is typical of a central London excavation. The site is partially underlain by Pleistocene river terrace deposits (Lynch Hill gravel), over Eocene London Clay and Harwich formation underlain by the Lambeth Group,
Thanet sand formation and Cretaceous Upper Chalk (BGS, 1994). Figure 1 illustrates the typical soil stratigraphy across the site.

Although there are two known aquifers below the site, no groundwater was recorded during the geotechnical investigations prior to excavation. This is likely a result of London Clay's low permeability. The site has a long history of rail-related industry, and, therefore, some contamination in the made ground and river terrace deposits was expected; indeed, $5 \%$ of the made ground and $3 \%$ of the river terrace deposits excavated were classified as hazardous under waste acceptance criteria. As expected with such a densely populated brownfield site, several services had to be diverted before excavation could begin.

\section{The propping system}

Fifty props were required for the construction of the box for Crossrail Paddington. The chosen props were sourced from Groundforce Shorco and were thought at that time to be the largest proprietary props available in the UK. Forty-two MP500 props spanned the width of the excavation, while two MP250 props were used in a raking configuration in each corner (Figure 2). All of the props were connected to $900 \mathrm{~mm} \times 600 \mathrm{~mm}$ fabricated plate girder walers, which in turn were connected to the $1 \mathrm{~m}$ thick diaphragm walls that bounded the construction. The props were designed for a factored ultimate limit state design geotechnical load of $7790 \mathrm{kN}$ and a temperature change of $+30^{\circ} \mathrm{C}$, creating a characteristic design load of $3203 \mathrm{kN}$. This

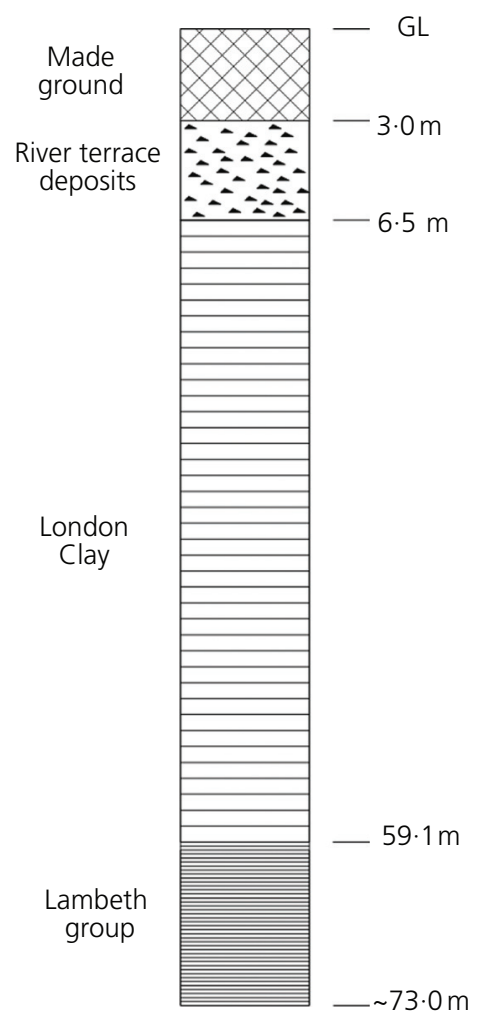

Figure 1. Ground profile at Crossrail Paddington 


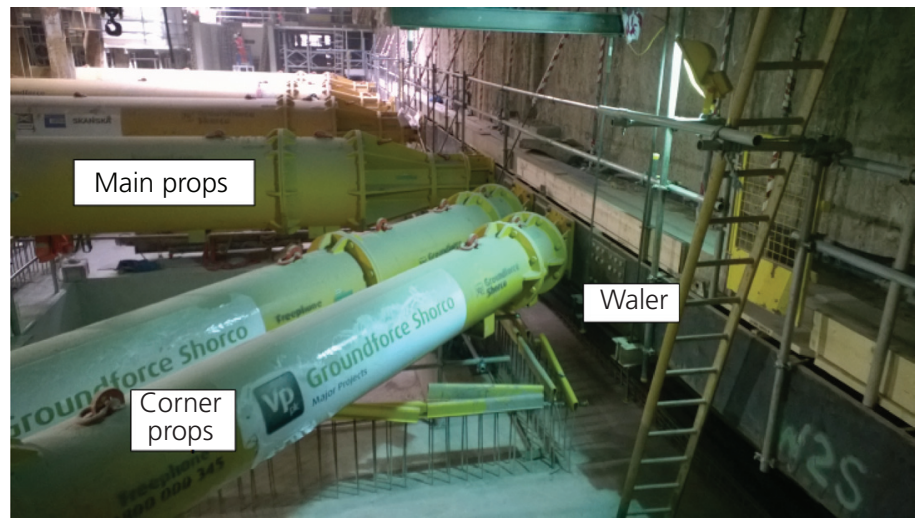

Figure 2. Photograph of the propping scheme in the south-west corner of the excavation

resulted in a total design load of $12010 \mathrm{kN}$ per prop. The manufacturer designed the props to provide a safe working load with a factor of 2.0 of $6250 \mathrm{kN}$. Therefore, their ultimate resistance was $12500 \mathrm{kN}$. In the event of accidental prop removal, the system was designed to be capable of resisting progressive collapse. Figures 3 and 4 show a plan of the propping layout and a typical cross-section of the structure respectively.

\section{Construction monitoring}

The data set generated during the construction phase of Crossrail Paddington is understood to be one of the most completely analysed to date due to several factors. The large number of props required for the construction phase, coupled with a cheaper and more reliable sensor technology, provided a great opportunity for collecting data. Many of the studies investigated as part of this project considered four props, whereas Paddington had a full-life data set of 36. The client's requirement for strict deformation control due to adjacent structures provided the need for collecting and analysing the large data set. Furthermore, the contractor required an accurate and complete understanding of ground deformations as they happened, as the effects of construction are often difficult to predict, despite improvements in numerical modelling. Although this project did not employ the observational method, it did have to meet a series of deformation targets at several stages of the construction process, and the monitoring data were used to validate some of the assumptions made in the design phase, particularly with respect to the behaviour around the tunnels.

Load pins were installed in 36 of the props, which transmitted load data every $15 \mathrm{~min}$ by using vibrating wire strain gauges. Four props had surface-mounted thermistors (a larger number was not feasible due to financial restrictions). Several panels of the large diaphragm wall that bordered the site contained inclinometers. These were able to give a picture of the deformation at the sides of the excavation and therefore the effect of the propping. As with any large construction project, a detailed set of documentation recorded the construction activities each day, and any discussions over events were noted in the data set. This allowed links to be made between features in the monitoring data and physical events in the construction sequence and variables such as ambient temperature.

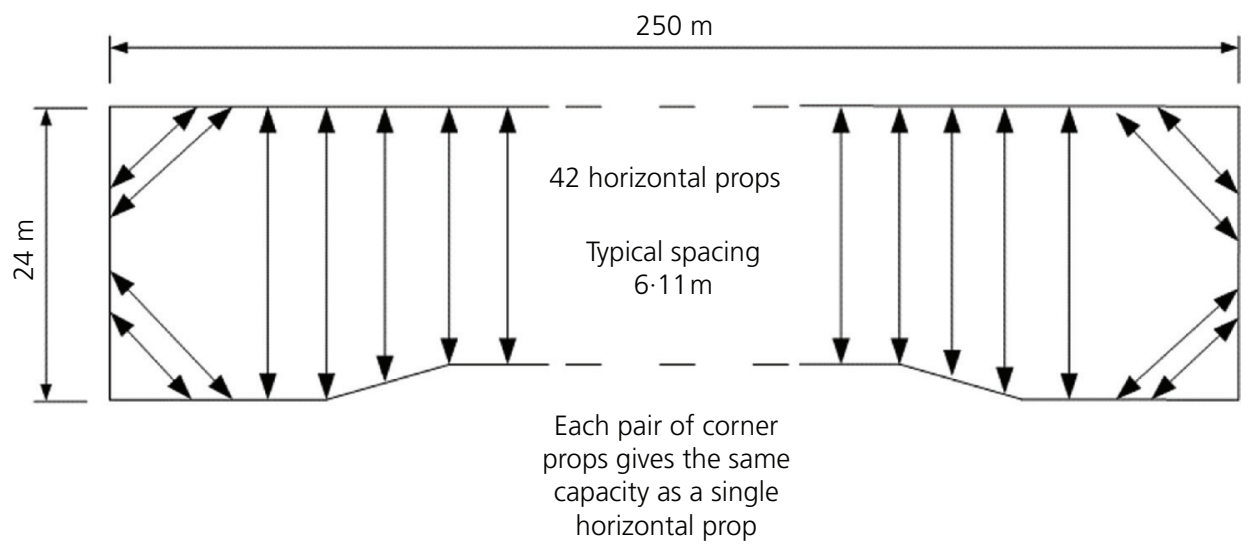

Figure 3. Plan of temporary propping layout 
Temporary propping at Crossrail

Paddington station

Chambers, Augarde, Reed and Dobbins

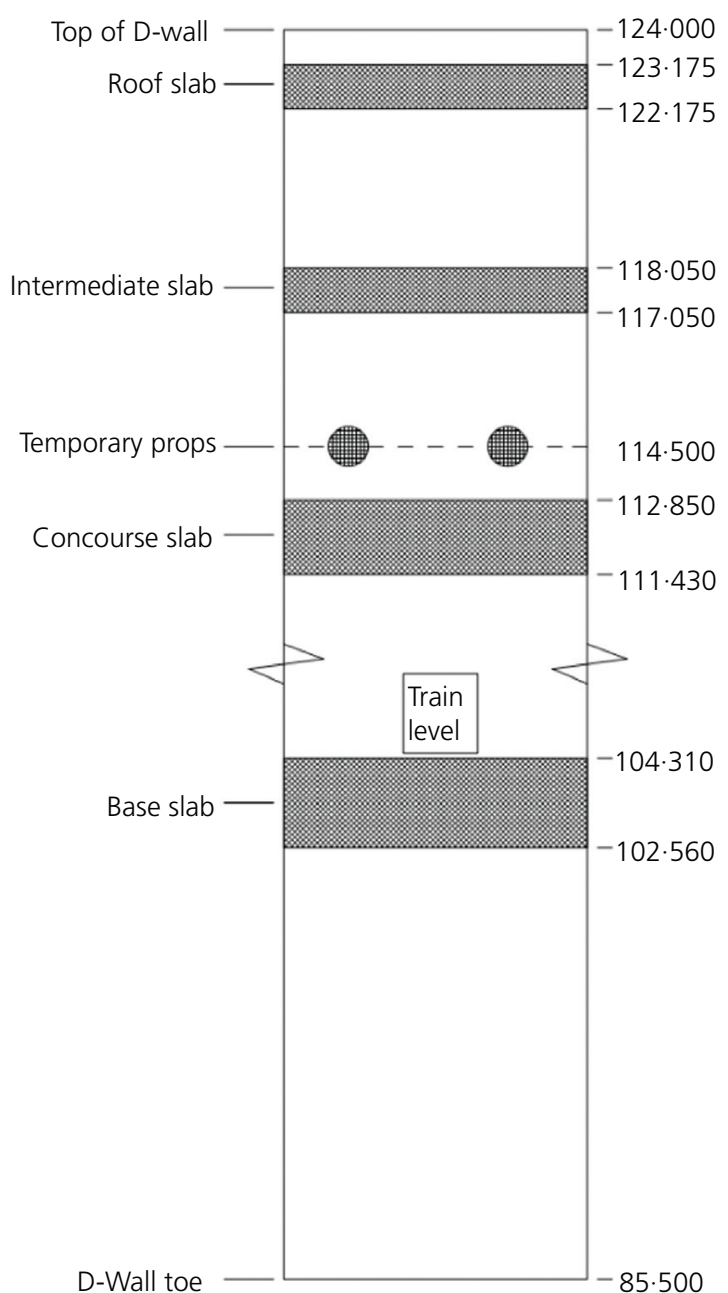

Figure 4. Section through structure including temporary propping. All levels are given in metres above tunnel datum
The following steps illustrate the flow of load and temperature data from the props to the site team.

- The prop load pin measures axial load every $15 \mathrm{~min}$.

- The load pin wirelessly transmits data to two recording stations situated at either end of the excavation.

- Recording stations transmit the load data to a remote server using the $3 \mathrm{G}$ mobile network.

In most cases the time bases used in sampling at the two recording stations were not consistent, which conveniently allowed the data streams to be merged for a higher data density over a given time period.

Before any conclusions could be drawn from the data, they had to be validated. Plots of load against time were produced on a scatter graph for each recording station on all of the props. This allowed comparison between the props and made it easier to identify anomalies visually. A number of errors were found and these are detailed in Table 1 along with the event that is understood to have caused them. The sources for these errors were found through meetings with the CSJV site team and consultation with Groundforce Shorco.

\section{Temperature effects}

Temperature variation in a partially exposed excavation Although there is guidance on considering temperature effects on exposed structures, such as bridge decks, few studies have explored the response of partially covered temporary propping to ambient temperature changes. Due to its top-down construction method, most of Paddington's propping system was covered by a partially complete roof slab (with access holes to the works below) and the tall structures on the site's boundary provided additional shade. Temperature on site was measured in three ways

- steel surface temperature thermistors on four of the props

- ambient air temperature taken from the two recording stations below the roof
Short gap in data stream for station A

Short gap in data stream for both stations in January Clipping of load data at $600 \mathrm{t}$

$7 \mathrm{~d}$ gaps in data for each site at different times Inconsistencies in CSV data sheet

One recording station lagging the other by $8 \mathrm{~d} 20 \mathrm{~min}$
Tracked vehicle damaged data cable for receiver station Vodafone updated mobile network mast to $4 \mathrm{G}$ Failure of vibrating wire strain gauge Recording station battery failure at both sites (not concurrent) Technician reassigned channel numbers on one station, possibly affecting data on the datum website Technician rebooted site A with site B start-up file after battery failure

Table 1. Errors and causes in load monitoring 
Geotechnical Research

Volume 3 Issue 1
Temporary propping at Crossrail

Paddington station

Chambers, Augarde, Reed and Dobbins
- external ambient temperature taken from total stations mounted on external buildings.

The readings from the total stations were collated for the nearest three to the works over the period from November 2013 to August 2014. Once plotted, it was clear that there was a good correlation between the total stations, so their data were merged. This allowed comparisons of the temperature measured above ground with the temperature measured below the roof slab and the surface temperature of the props. This information is shown in Table 2.

The prop surface temperature follows the same trends as the internal and external temperatures, but with a much smaller amplitude. As can be seen in Table 2, the prop experiences a much smaller temperature variation during its lifespan $\left(16^{\circ} \mathrm{C}\right)$ compared with the design value $\left(30^{\circ} \mathrm{C}\right)$, suggesting that this parameter was overconservative for a partially covered excavation.

\begin{tabular}{lrcc}
\hline & $\begin{array}{c}\text { Prop: } \\
{ }^{\circ} \mathrm{C}\end{array}$ & $\begin{array}{c}\text { Internal ambient: } \\
{ }^{\circ} \mathrm{C}\end{array}$ & $\begin{array}{c}\text { External ambient: } \\
{ }^{\circ} \mathrm{C}\end{array}$ \\
\hline Maximum & $20 \cdot 87$ & 30 & 32 \\
Minimum & 4.57 & 2 & -0.8 \\
Difference & 16.3 & 28 & 32.8
\end{tabular}

Table 2. Prop, internal and external ambient temperatures

\section{Daily thermal variation}

Closer inspection of the daily temperature variation also provides some useful insight. Figure 5 shows the thermal load variation for a prop on 27 April as an example. The prop spans the station towards the east end of the structure. The lowest temperature was recorded around 8 a.m., and the highest around 7 p.m. (this varied by around an hour depending on the season). This load variation manifested itself to the site team during prop removal. It was discovered that after midday the prop was under too much load to be removed without cutting the waler, despite the thermal load variation being smaller than expected in the design phase. This finding indicates times of day suitable (and unsuitable) for prop removal on future schemes.

\section{System stiffness}

The expected thermal load in a prop was $3202 \mathrm{kN}$; however, the measured data were closer to $1000 \mathrm{kN}$ over the entire construction period. The change in temperature was less than expected, but this does not account for all of that difference. Design guidance for thermal loads in props is found in the paper of Gaba et al. (2003), where

$$
\text { 1. } \Delta P=\alpha E A \delta T\left(\frac{\beta}{100}\right)
$$

In Equation 1, $\Delta P$ is the change in thermal load, $\alpha$ is the thermal coefficient of the prop material, $E$ is the Young's modulus of the prop material, $A$ is the cross-sectional area of the prop, $\delta T$ is the change in temperature and $\beta$ is the system stiffness. Paddington was bounded by $1 \mathrm{~m}$ thick heavily reinforced diaphragm walls in

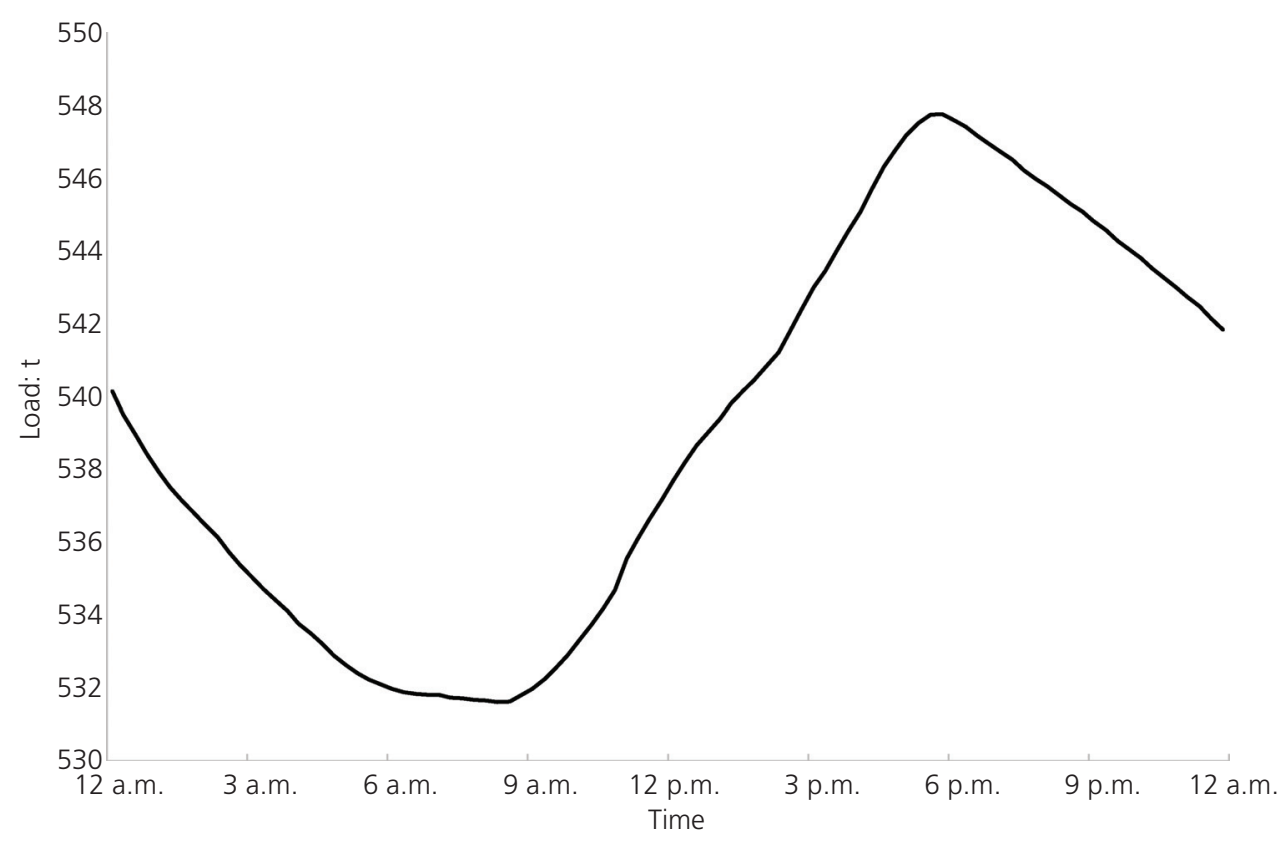

Figure 5. Thermally induced load variation for a prop on 27 April

2014 
stiff London Clay, and so a value of $\beta=70$ was chosen during the design. $\delta T$ was specified by the designer as $+30^{\circ} \mathrm{C}$. The material parameters for steel are well understood and have little variation, so it was decided that the system stiffness, or the degree of restraint, warranted further investigation.

The thermally induced loads and the surface temperatures were used to back-analyse the system stiffness for all of the props with surface temperature monitoring. Thirty-six daily cycles were sampled. The results of this are shown in Table 3. These results are similar to those presented in a study conducted at Crossrail Royal Oak portal (Ivanova, 2012) and suggest that the $\beta$ value for stiff walls in stiff clay is better set to 50 rather than 70 .

The overall effect of the combination of a lower than expected system stiffness and a lower temperature variation is considerable. The design thermal load was $3202 \mathrm{kN}$, and the largest thermal load using the maximum observed system stiffness and temperature variation was $1136 \mathrm{kN}$ - that is, $35 \%$ of the expected value. The largest daily variation was $167 \mathrm{kN}$. Based on currently accepted procedures used in the industry, it appears that there is potential for considerable economy in propping works of this nature.

\begin{tabular}{lc}
\hline & $\beta$ \\
\hline Minimum & $12 \cdot 4$ \\
Maximum & $45 \cdot 8$ \\
Average & $35 \cdot 1$
\end{tabular}

Table 3. System stiffness results

\section{Construction sequence}

A better understanding of the effects of different events in the construction process can not only highlight potential economies to be gained but also lead to the design of safer systems. The prop load data at Paddington were compared with information from the site diaries to explore the effect of different items of construction work.

\section{Slab installation}

One of the most notable features in the load trends for each prop was the 'ticks' in the load. Figure 6 illustrates this feature. In this case, a horizontal prop is directly above a section of the concourse slab (both towards the west of the excavation). Before the slab is cast, the prop is consistently recording loads of between 4900 and $5000 \mathrm{kN}$. The slab is cast in the night shift of 1 February, and there is a sudden drop in the prop load to $3950 \mathrm{kN}$ by the morning of 3 February. This means that the prop load drops by $20 \%(1000 \mathrm{kN})$ in just under $2 \mathrm{~d}$. The load returns to its previous value on the night shift of 7 February. After this, the prop load continues to increase at a more gradual rate up to, and later passes, the serviceability limit state (SLS) design load. A similar effect can be seen from the adjacent slab that was cast later, but at a much smaller magnitude.

When the slab is poured, it behaves as a fluid and will exert a hydrostatic pressure outwards on the wall. However, the concrete curing process will create heat (because it is an exothermic chemical interaction). The high pulverised fuel ash content of the concrete, along with the geometry of the slab ( $\sim 1.5 \mathrm{~m}$ deep), suggests a likely maximum temperature of approximately $60^{\circ} \mathrm{C}$. Because the slab will be hotter than the ambient pour temperature $\left(\sim 8^{\circ} \mathrm{C}\right.$ in winter to $\sim 20^{\circ} \mathrm{C}$ in summer), it will expand. However, it is restrained by the diaphragm walls on either side. A typical degree of restraint is given as 0.25 for this situation (interview with N. Busby, chief materials engineer of Skanska UK,

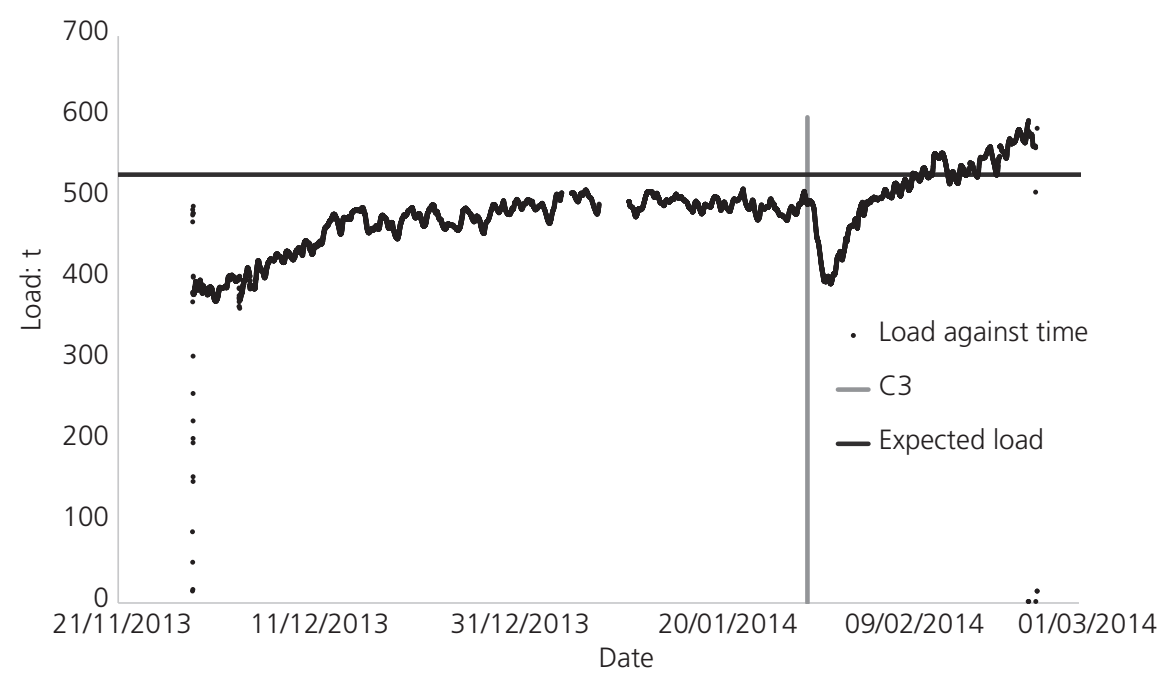

Figure 6. Load trend of a horizontal prop over its lifespan. Tick feature lines up with the casting of a slab below it 
28 August 2014). It is hypothesised that as the slab expands, it pushes the diaphragm walls out of the excavation and, thus, relieves load from the props. As the slab cures further, it will contract and pull the diaphragm walls back into the excavation, increasing the prop loads to their earlier level or more. In many cases this behaviour appears to have loaded a prop over its SLS load value. Strain gauges and thermistors in the slab would permit further investigation of this behaviour.

\section{Prop removal}

Removing adjacent props caused a load redistribution in the propping system. However, as a slab had been cast and cured below the props, it is likely that the majority of the load they were carrying was transferred to the slab below them. This resulted in a small change in prop load compared with the total load. Therefore, in the case of Paddington, removing adjacent props did not have any great impact on the prop loads or the construction process.

\section{Excavation}

After a prop was installed on a day shift, excavation proceeded towards the south-east in the night shift. This excavation lowered the passive earth resistance in front of the wall and therefore is expected to have increased the prop load. It is possible that this is represented by the rate of prop load increase, illustrated in Figure 7. The overlain curve shows how the rate of load increase varies with time. The rate of load gain decreases as the excavation progresses. This trend was not significant in all props.

\section{Prestressing the props}

Establishing the model

All of the props used in the construction of Paddington were preloaded to $70 \%$ of their design value. This meant that the load data could not show how deflections varied with prestress. A numerical model was required in order to do a parametric study of the effect of varying prestress. It was decided that a $2 \mathrm{D}$ plane strain analysis would be suitable for this task, in part due to the linear nature of the site and also due to software availability. Both the finite-element software Plaxis and the spring stiffness software Wallap were used by the designers (Scott Wilson). However, the options for soil models and the availability of support at Durham made Plaxis more suitable for this study. The model was based on a section through the excavation that had reliable results for load and deflections from inclinometers installed in the diaphragm wall. Once the deflected profile of the model matched the profile measured by the inclinometer, an analysis of the sensitivity of different parameters was undertaken. The results of this were then compared with those of previous studies. When the model mimicked the results measured on site, the prop preload could be varied to see its impact on wall deflections. Unfortunately, due to time constraints, this experiment was conducted on only one section of the works. The data for future evaluation of sections are in existence and controlled by the principal contractor for the works.

An important consideration is the choice of soil constitutive model. Plaxis provides a number of in-built models as well as the option of creating a user-defined model. It was decided that developing a user-defined model was beyond the scope of this project (again due to time limitations). Previous studies on the suitability of material models in Plaxis 2D to different purposes indicated that the hardening soil (HS) model is appropriate for excavations (Xu and Wang, 2010). The HS model simulates nonlinear soil behaviour with shear hardening (Schanz et al., 1999). With a small modification, the hardening soil model becomes the HS small model, which also considers the small elastic region for

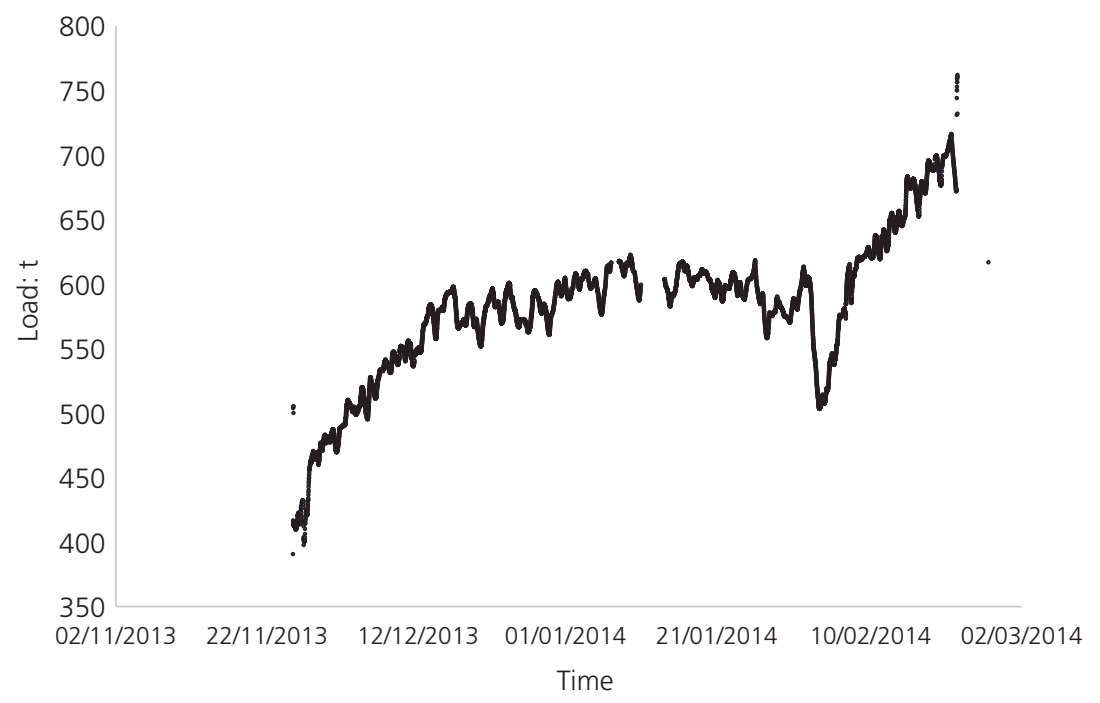

Figure 7. The rate of load gain decreases after the beginning of the prop's lifespan due to excavation, becoming steady until a slab is cast below it 
Geotechnical Research

Volume 3 Issue 1
Temporary propping at Crossrail

Paddington station

Chambers, Augarde, Reed and Dobbins

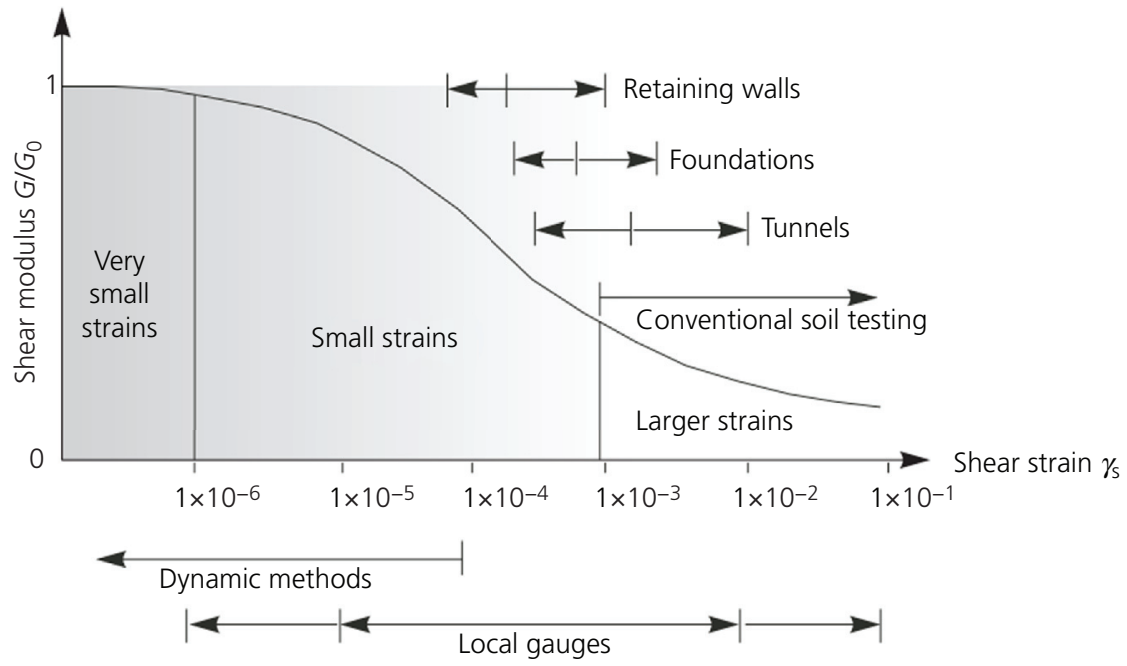

Figure 8. Characteristic strain-stiffness behaviour of soil with typical strain ranges for laboratory tests and structures

strain-dependent stiffness (Schanz et al., 1999). Figure 8 shows that this problem requires consideration of smaller stains than other geotechnical design areas.

\section{Prestress results}

The aim of preloading is to remove any potential shortening from the propping system before it is put into service. This will limit wall movements into the excavation and the settlement of neighbouring structures. All of the props in Paddington were preloaded using hydraulic jacks to create a load of $700(\mathrm{kN} / \mathrm{m}) / \mathrm{m}$ in the walers, which typically equated to around $4000 \mathrm{kN}$ for the horizontal props (the prop spacing varied, but was generally about $6 \cdot 1 \mathrm{~m}$ ). The props were loaded to this level using both their main hydraulic jack and a system of two additional 'auxiliary jacks' that had to be specially developed for this contract to achieve the specified degree of prestress (Figure 9). This section will explain the investigation of the optimum prop load using a parametric study in Plaxis.

A cross-section of the works which had in-built inclinometers in the diaphragm wall panels was chosen to compare the model against. The excavation was modelled in $1 \mathrm{~m}$ layers, and the diaphragm walls were 'wished in place'. The model geometry (diaphragm walls, slabs and props) was the same as that used for construction. The ground profile and the structural layout as specified in the Plaxis model are shown in Figure 10. The mesh density was specified as 'high' with extra refinement around the soil-structure interface.

The soil parameters chosen for the HS small soil model were mainly derived from the factual geotechnical report (Crossrail

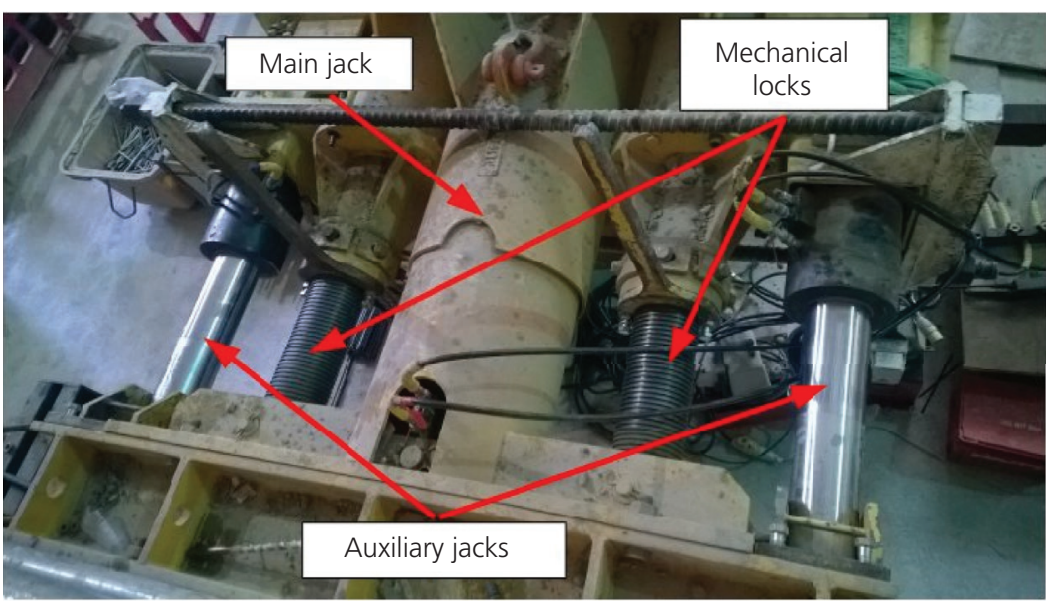

Figure 9. Photograph of the auxiliary jacking system, required to reach $70 \%$ prestress 
Temporary propping at Crossrail

Paddington station

Chambers, Augarde, Reed and Dobbins

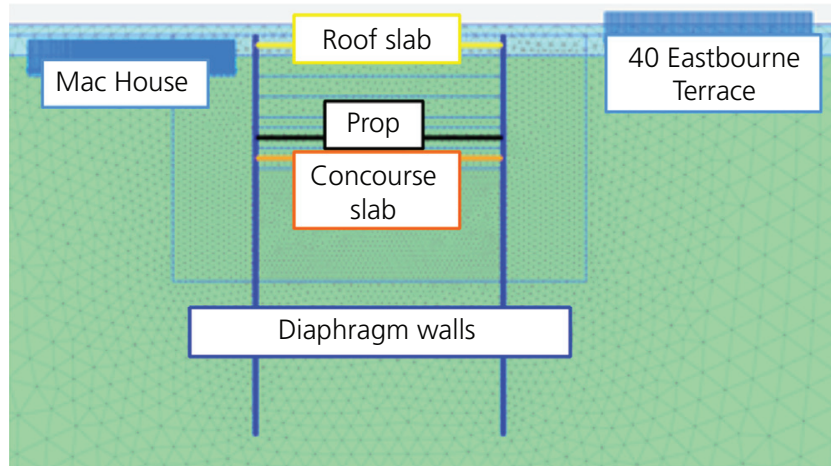

Figure 10. Mesh and structural layout of Crossrail Paddington section (Plaxis model). The top layer of soil is made ground, with the main soil mass being London Clay

Limited, 2010). A number of assumptions about the simulation were made.

- The tunnels were not present: two tunnels ran below the site, but it was assumed that they transmitted the load through the soil structure perfectly.

- River terrace deposits: this soil layer was thin compared to the made ground and London Clay and was near the surface, so it was assumed to be part of the London Clay strata.

- Structural elements: all structural elements were modelled as linear elastic isotropic materials.

- Excavation: the excavation was kept dry, and there is no groundwater flow through the London Clay.

- Drainage: the model was set as 'Undrained B', which uses undrained effective stress with undrained strength parameters.

\begin{tabular}{|c|c|c|}
\hline Parameter & Symbol & Value \\
\hline Unit weight & $\gamma$ & $20 \mathrm{kN} / \mathrm{m}^{3}$ \\
\hline Secant stiffness & $E_{50}$ & $40 \times 10^{3} \mathrm{kN} / \mathrm{m}^{2}$ \\
\hline Odeometer stiffness & $E_{\text {oed }}$ & $40 \times 10^{3} \mathrm{kN} / \mathrm{m}^{2}$ \\
\hline Un-/reloading stiffness & $E_{\mathrm{ur}}$ & $120 \times 10^{3} \mathrm{kN} / \mathrm{m}^{2}$ \\
\hline Shear strength reference & Suref & $122 \cdot 5 \mathrm{kN} / \mathrm{m}^{2}$ \\
\hline Shear strain at $0.7 G_{0}$ & $\gamma_{0.7}$ & $0.968 \times 10^{-3}$ \\
\hline Reference shear modulus & $G_{0}$ & $50 \times 10^{3} \mathrm{kN} / \mathrm{m}^{2}$ \\
\hline $\begin{array}{l}\text { Un-/reloading loading } \\
\text { Poisson's ratio }\end{array}$ & $v_{\mathrm{ur}}$ & $0 \cdot 2$ \\
\hline Reference pressure & $P_{\text {ref }}$ & $100 \mathrm{kN} / \mathrm{m}^{2}$ \\
\hline $\begin{array}{l}\text { Normally consolidated } \\
\text { in-situ earth pressure }\end{array}$ & $K_{\text {Onc }}$ & $1 \cdot 0$ \\
\hline $\begin{array}{l}\text { Incremental shear } \\
\text { strength }\end{array}$ & $S_{\text {uinc }}$ & $5 \mathrm{kN} / \mathrm{m}^{2}$ \\
\hline OCR & $R_{\mathrm{OC}}$ & $6 \cdot 54$ \\
\hline
\end{tabular}

Table 4. HS small soil parameters for London Clay
Table 4 shows the soil parameters for the London Clay.

Some of the soil parameters were taken straight from the site investigation data (Crossrail Limited, 2010). However, some of the other material parameters were trickier to find. There appears to be little agreement over the means of calculating the overconsolidation ratio (OCR) and the shear strain at $70 \%$ of the reference modulus. The reference shear modulus of London Clay has not been documented in this context before. However, recent research suggested some relationships that can be used to calculate these parameters. These 'first estimates' were then varied until the Plaxis wall deflection matched the measured wall deflection.

A sensitivity analysis was conducted before the parametric study. The study indicated that $\gamma_{0.7}$ and the shear modulus had a significant impact on the wall displacements. Doubling the shear modulus decreased the maximum wall displacement to $75 \%$ of its original value. Similarly, increasing $\gamma_{0.7}$ caused an increase in displacement.

Although no precedence of the HS small model with London Clay was found in the literature, a recent work by Vardenega and Bolton (2011) provided starting points for the values $\gamma_{0 \cdot 7}$ and $G_{0}$. The authors suggested that the shear modulus of London Clay can be related to the shear strength by

2. $G_{0}=320 \cdot 7 S_{\mathrm{u}}$

which provides a value of $39 \cdot 3 \mathrm{MPa}$ for the clay at Paddington. However, Plaxis would not allow this value to be smaller than $50 \mathrm{MPa}$. Vardenega and Bolton (2013) suggested that the reference shear strain can be related to the index of plasticity by

3. Reference shear strain at $50 \% G_{0}=2 \cdot 2\left(\frac{I_{\mathrm{p}}}{1000}\right)$

The site investigation for Paddington provided detailed results for the plasticity index $I_{\mathrm{p}}$ (Crossrail Limited, 2010). This was smaller than the value at $0 \cdot 7 G_{0}$ but should suffice for this model. London Clay is heavily overconsolidated due to glacial action. Vardenega and Bolton (2013) again provide an empirical relationship for the OCR $\left(R_{\mathrm{OC}}\right)$ as

4. $R_{\mathrm{OC}}=\left[\frac{s_{\mathrm{u}} / p_{\mathrm{o}}^{\prime}}{0 \cdot 11+0 \cdot 0037\left(I_{\mathrm{p}}\right)}\right]^{1 \cdot 25}$

The confining pressure $p_{\mathrm{o}}^{\prime}$ in the undrained triaxial tests used in the site investigation was $100 \mathrm{kPa}$. This provides an OCR of 6.54 for the clay at Paddington.

The calibrated model had a maximum wall deflection of $15.65 \mathrm{~mm}$ compared with the inclinometer value of $13 \mathrm{~mm}$, both at the same level (103.5 $\mathrm{m}$ above tunnel datum level). Therefore, the modelled deflection is $2.65 \mathrm{~mm}$ larger than the measured one (Figure 11). 


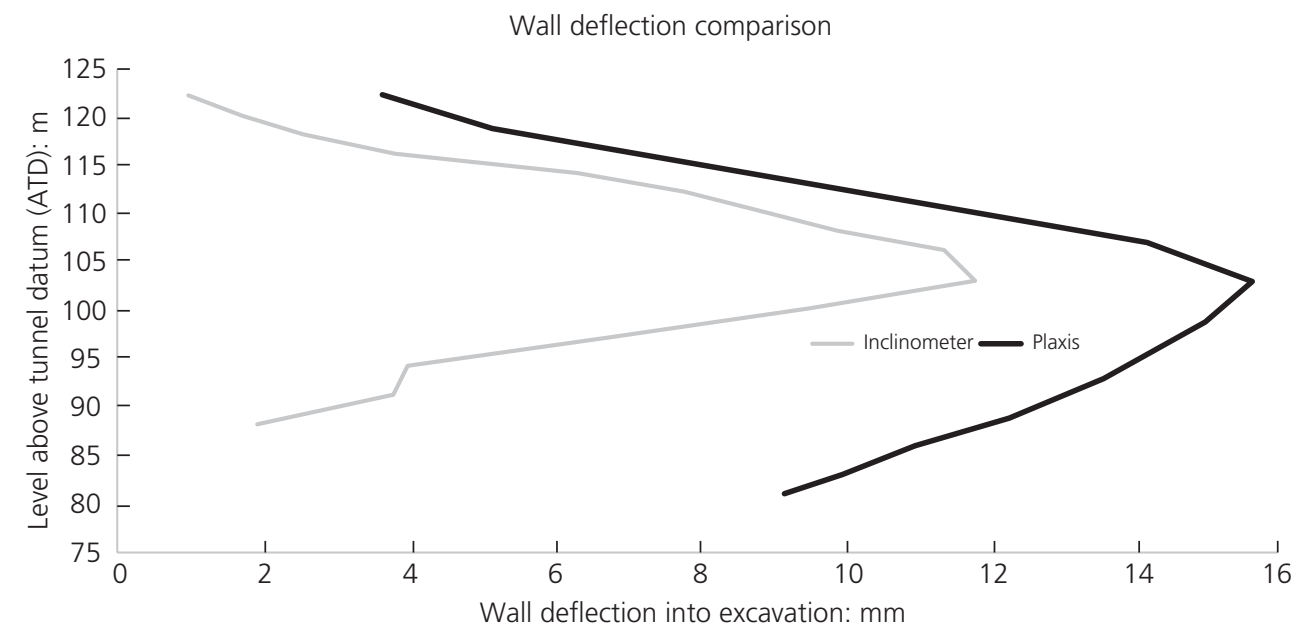

Figure 11. Comparison of wall deflection between inclinometers and (site data) and FEA results

The prop preload was varied to provide the maximum wall displacements found in Table 5 .

A drop in prop load of $2427 \mathrm{kN}$ results in an increase in diaphragm wall displacement of $0.45 \mathrm{~mm}$. The small impact of the preload is likely to be a reflection of the stiffness of the London Clay and structural elements (diaphragm walls and roof slabs). It is suggested that the propping system considered in this paper should have been preloaded to $30 \%$, an extent that removed slack in the system connections. This would have dispensed with the need for specialist jacking systems and the operatives required for them, leading to financial, safety and programme efficiency gains.

\section{Behaviour of the corner props}

The corner props in Paddington recorded smaller loads than those predicted in the design phase. This is consistent with projects discussed in the literature in the section 'Previous research in open excavation monitoring'. This section postulates some reasons for this observation. Two raking props were installed in each corner of the excavation to support the headwall. These props did not show the same trend of load increase as the main spanning props. The first four props installed exhibited thermal load variation but no overall increase in load from the prestress values. Three of the other four corner props showed some increase in load, but still spent the majority of their operational lives below their preload values and one of them shed $50 \%$ of its preload. This prop was tested when this feature was noted and was found to be performing correctly. The supplier indicated that this phenomenon had been seen elsewhere, but no reason has yet been found for such behaviour (interview with S. Lloyd, design engineer of Groundforce Shorco, 15 August 2014).

In order to investigate both the general trend of corner props measuring less load than expected and the specific case of Paddington, a qualitative model was developed in the three- dimensional (3D) finite-element package Abaqus. The available version of the software had a limitation on the number of Gauss points, which restricted modelling capabilities. Therefore, this section of the paper illustrates the beginning of an avenue of research that is being continued in 2016 at Durham University. The aim of this exercise was to explore the load paths and modes of deformation in the retaining wall corners. Several simplifying assumptions were made.

n The load on the walls is modelled as a surface pressure.

- The walls are fixed for displacement at the point of embedment (where there is soil on both sides of the wall). Rotation is permitted.

- The box is symmetrical about the centre of the long wall, saving elements and therefore computational runtime.

- Although the retaining walls are composed of individual panels, they act as a single continuum.

- No supports (props or slabs) are modelled so that the wall behaviour can be better seen.

The walls were configured as linear elastic continuum elements with a Young's modulus $E$ of $17 \mathrm{GPa}$ and a Poisson's ratio $v$ of $0 \cdot 21$. As one would intuitively expect, the displacement of the

Prop preload: kN Maximum wall displacement: $\mathrm{mm}$

\begin{tabular}{ll}
\hline 2000 & $16 \cdot 10$ \\
3000 & $15 \cdot 90$ \\
4247 (actual) & $15 \cdot 65$ \\
5000 & $15 \cdot 50$ \\
6000 & $15 \cdot 31$
\end{tabular}

Table 5. Impact of prop preload on maximum wall displacements 
long wall sections was significantly greater than that of the headwalls. One method of exploring the 3D behaviour of the wall is to assign the corners of the box different values of stiffness. This artificially separates the walls, which is how the system is designed in industry (Figure 12). Table 6 shows the impact of assuming that the walls act independently. Positive displacements are into the excavation.

The results suggest that when the structure is homogeneous, the behaviour of the headwall is affected by the behaviour of the longer main wall (in the rectangular case of Paddington). The large main wall displacements are due to the assumptions of this qualitative model (such as no propping). When the stiffness of the corners is lowered to simulate a discontinuity, the walls behave as individual simply supported beams. This could necessitate a reassessment of the current design practice for retaining wall structures with corners. There appears to be limited code guidance for designers; indeed, the current edition of Ciria C580 recommends further investigation into corner effects to develop industry knowledge (Gaba et al., 2013). The design process at Paddington appears to be typical. Each wall is treated as an individual simply supported beam, with a load from the soil and supports composed of props and connections to other walls. A simple beam analysis can therefore provide prop loads. However, it is likely that the connected walls will have an effect on the headwall rather than act as supports, as illustrated in Figure 12.

Instead of considering the headwall to be a simply supported beam, it could perhaps be better analogised as the top of a thin portal frame. The inward deflection of the long main walls creates a hogging moment (tension on the outside of the structure) in the top span. This will lower the effect of the sagging moment in the span caused by the earth load. The lower resultant moment could

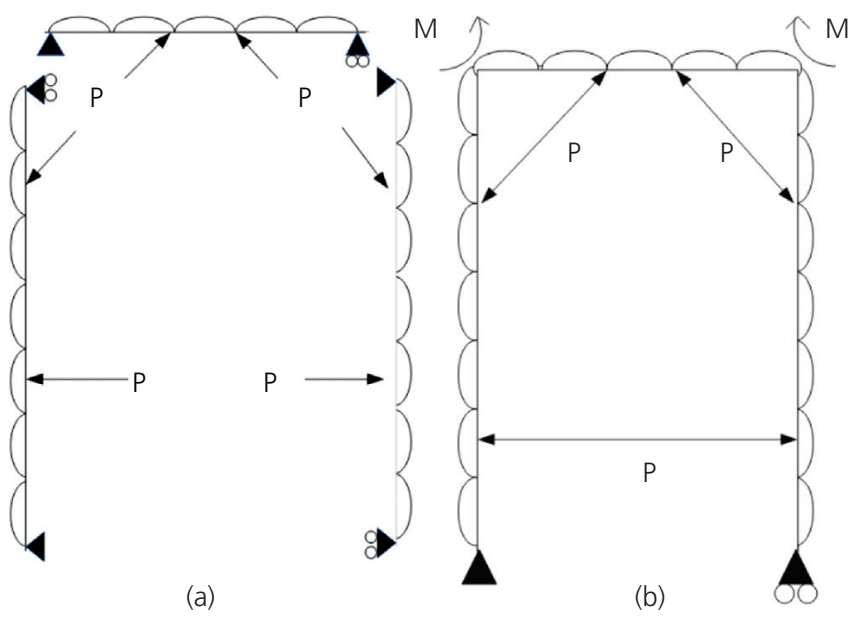

Figure 12. (a) Sketch showing current design philosophy for box retaining structures. Each wall is considered as a simply supported beam. (b) Possible alternative design philosophy for box retaining structures. Box behaves similarly to a portal frame, with the corners carrying moment

\begin{tabular}{lcc}
$\begin{array}{l}E_{\text {corner }} / \\
E_{\text {wall }}\end{array}$ & $\begin{array}{c}\text { Headwall displacement: } \\
\mathrm{mm}\end{array}$ & $\begin{array}{c}\text { Main wall displacement: } \\
\mathrm{m}\end{array}$ \\
\hline 1 & -0.8 & $1 \cdot 5$ \\
0.9 & -0.009 & 1.6 \\
0.5 & $5 \cdot 8$ & 1.6 \\
0.1 & 610 & $2 \cdot 5$
\end{tabular}

Table 6. Wall displacements with differing corner stiffnesses

lead to lower deflections and therefore smaller prop loads. It is worth highlighting that if the wall was to move into the retained soil, it would create a higher earth pressure, so it is suggested that the deflections considered in this hypothesis are very small.

In the case of Paddington, there is a more significant factor in the small corner prop loads. Short sections of the intermediate slab were cast $8 \mathrm{~m}$ out from each headwall, to be continued later in the construction process. This deviation from the traditional top-down construction method resulted in slabs that are likely to have behaved like permanent props. On closer inspection of the contractor's design calculations, it appears that a scheme without headwall propping was considered. However, it also appears that the intermediate slab ends would have had to be $10 \mathrm{~m}$ long instead of $8 \mathrm{~m}$ to be suitable. Therefore, the difference in measured corner prop loads investigated in this report is quite site-specific, much like that in the previous research in this area (Gaba et al., 2013). The hypothesis that the corners of this type of diaphragm wall carry some degree of moment is perhaps worth further investigation, as is the possibility of soil arching distributing the load around the corners.

\section{Potential savings}

This research has explored several possible areas for efficiency gains in propping systems. To illustrate their impact, the financial savings that could have been achieved at Paddington with the findings this research are briefly investigated.

Although the measured thermal loads were considerably smaller than the design values, it is difficult to say whether fewer props or a larger spacing would have been suitable without fully redesigning the propping system. This is deemed to be beyond the scope of the project. However, the findings in relation to the prestressing and the low corner prop loads at Paddington provide some savings. A subagent from the construction of Paddington provided rates for material cost and haulage, labour rates and the labour required for this work and details on equipment rental costs, from which approximate predicted financial savings were calculated (Table 7) (S. Reed, personal communication).

This number does not consider all of the benefits to the programme that come with installing fewer props and walers, as well as the cost of designing the headwall walers. The safety 


\begin{tabular}{lr}
\hline Saving & Value: $f$ \\
\hline Jacking system & 34200 \\
Walers & 38100 \\
Prop rental & 45340 \\
Risk of delay $(10$ d) & 7200 \\
Total & 124800
\end{tabular}

Table 7. Approximate potential cost savings (excluding valueadded tax)

benefits of installing fewer props cannot be quantified. However, considering these possible savings alone account for around 15\% of total cost for the propping system.

Although approximate, these results indicate that there are significant economies to be made in the design of propping systems

\section{Conclusions}

This paper records the investigation and analysis of the temporary propping system used in the construction of Crossrail Paddington station while also considering the wider industry design of temporary propping systems. The measured temperature variation on the prop surfaces was approximately half of that specified at the design stage, indicating considerable thermal damping in partially exposed systems. The stiffness of the propping system was backcalculated and compared with the design value. It was found that the system stiffness averaged $35 \%$, compared to the $70 \%$ recommended in the design guide, Ciria C580. The combination of these factors resulted in a maximum measured thermal load of approximately $1000 \mathrm{kN}$, compared with a design thermal load of $3202 \mathrm{kN}$.

A parametric study using the finite-element software Plaxis was undertaken to explore the impact of different levels of prestress in the propping system. While the system at Paddington was prestressed to $70 \%$ of its SLS design value, the results of the study indicate that this was not necessary. A preload of $30 \%$ resulted in wall deflections well within the trigger values. Therefore, the additional jacking system that had to be developed for the $70 \%$ preload could have been avoided. This has fiscal and programme benefits.

The corner props at Paddington measured significantly lower loads than expected. Some possible reasons for this are considered. The existence of a section of intermediate slab and the roof slab above the corners are likely to have accounted for the majority of this. However, a qualitative study in the $3 \mathrm{D}$ finite-element package Abaqus indicates that there is a potential weakness in the current design philosophy for 3D retaining walls. Instead of designing each side of a retaining wall as an individual simply supported beam, it could perhaps be more realistically considered as a portal frame. The measured prop loads and comments from designers indicate that the corner props, and therefore the headwall walers, could potentially have been avoided at Paddington. Again, this brings significant fiscal and programme savings. These savings were roughly quantified, suggesting that the findings of this research could have saved the client over $£ 100000$.

\section{Acknowledgements}

The authors wish to thank Costain-Skanska Joint Venture and Groundforce Shorco for making the data used in this research available and Crossrail Limited for permission to conduct this research. The engineering department at Skanska contributed a great deal of knowledge and enthusiasm to this work. Paul Cole, Dimitrios Selementas and Luke Carolan are thanked for their advice and support.

\section{REFERENCES}

BGS (British Geological Survey) (1994) 1:50,000 Series Geological Map, Solid and Drift - London Sheet 256. BGS, London, UK.

Burland J and Kalra J (1986) Queen Elizabeth II conference centre: geotechnical aspects. Proceedings of the Institution of Civil Engineers, Part 1 - Design and Construction 80(6): 1479-1503, http://dx.doi.org/10.1680/iicep.1986.527.

Ciria (Construction Industry Research and Information Association) (2014) C580 Update: Collaborative Industry Workshop Held with Arup. Ciria, London, UK. See http://www.ciria.org/News/ blog/c580 update.aspx (accessed 06/01/2015).

Crossrail Limited (2010) Geotechnical Design Report: Part 2, Geotechnical Design Summary Report. Crossrail Limited, London, UK.

Fourie A and Potts D (1985) The effect of wall stiffness on the behaviour of a propped retaining wall. Géotechnique 35(3): 347-352.

Gaba A, Simpson B, Powrie W and Beadman D (2003) C580: Embedded Retaining Walls - Guidance for Economic Design. Ciria, London, UK.

Gourvenec S, Powrie W and De Moor W (2002) Three dimensional effects in the construction of a long retaining wall. Proceedings of the Institution of Civil Engineers Geotechnical Engineering 155(3): 163-173, http://dx.doi.org/ 10.1680/geng.155.3.163.38682.

Hansford M (2012) No. 11 Nicoll Highway collapse. New Civil Engineer, 2 May. See http://www.nce.co.uk/features/nce-40years/no11-nicoll-highway-collapse/8629881.article (accessed 06/01/2014).

Ivanova K (2012) Monitoring and Analysis of Temporary Prop Loads at Crossrail Royal Oak Portal. Skanska UK, London, UK.

Loveridge F (2001) Evaluation of Prop Loads at Channel Tunnel Rail Link Contract 430 - Ashford Tunnels. British Geotechnical Association, London, UK.

Marchand S (1997) Temporary support to basement excavations and strut load monitoring. Proceedings of the Institution of Civil Engineers - Geotechnical Engineering 125(3): 141-154, http://dx.doi.org/10.1680/igeng.1997.29465.

Powrie W and Batten M (2000) Comparison of measured and calculated temporary prop loads at Canada Water station. 
Géotechnique 50(2): 127-140, http://dx.doi.org/10.1680/geot. 2000.50.2.127.

Powrie W and Li E (1991) Analysis of in-situ retaining walls propped at formation level. Proceedings of the Institution of Civil Engineers, Part 2 91(4): 853-873, http://dx.doi.org/10. 1680/iicep.1991.17493.

Richards D, Holmes G and Beadman D (1999) Measurement of temporary prop loads at Mayfair car park. Proceedings of the Institution of Civil Engineers - Geotechnical Engineering 137(3): 165-174, http://dx.doi.org/10.1680/gt. 1999.370305.

Richards D, Powrie W, Roscoe H and Clark J (2007) Pore water pressure and horizontal stress changes measured during construction of a contiguous bored pile multi-propped retaining wall in Lower Cretaceous clays. Géotechnique 57(2): 197-205.

Schanz T, Vermeer P and Bonnier P (1999) The hardening soil model: formulation and verification. In Beyond 2000 in Computational Geotechnics (Brinkgreve RBJ (ed.)). Plaxis. Amsterdam, the Netherlands, pp. 281-296.

Simic M and French D (1998) Three-dimensional analysis of deep underground stations. In The Value of Geotechnics in Construction: Proceedings from the Seminar, Institution of Civil Engineers, London, 4 November 1998. Construction Research Communications, London, UK, pp. 93-100.
Simpson B and Powrie W (2001) Embedded retaining walls: theory, practice and understanding. In Proceedings of the 15th International Conference on Soil Mechanics and Geotechnical Engineering, Istanbul, Turkey. International Society for Soil Mechanics and Geotechnical Engineering, London, UK, pp. 2505-2524.

Stroud M, Hutchinson M, St-John H and Yarwood N (1994) Loads on struts in excavations. Proceedings of the Institution of Civil Engineers - Geotechnical Engineering 107(4): 241-246, http://dx.doi.org/10.1680/igeng.1994.26965.

Vardenega P and Bolton M (2011) Predicting shear strength mobilisation of London clay. In Proceedings of the 15th European Conference on Soil Mechanics and Geotechnical Engineering: Geotechnics of Hard Soils - Weak Rocks, Athens, Greece. IOS Press, Amsterdam, the Netherlands, vol. 1, pp. 487-492.

Vardenega P and Bolton M (2013) Stiffness of clays and silts: normalising shear modulus and shear strain. Journal of Geotechnical and Geoenvironmental Engineering 139(9): 1575-1589, http://dx.doi.org/10.1061/(ASCE)GT.1943-5606. 0000887.

Xu W and Wang W (2010) Selection of soil constitutive models for numerical analysis of deep excavations in close proximity to sensitive properties. Chinese Journal of Rock and Soil Mechanics 31(1): 258-264.

\section{WHAT DO YOU THINK?}

To discuss this paper, please submit up to 500 words to the editor at journals@ice.org.uk. Your contribution will be forwarded to the author(s) for a reply and, if considered appropriate by the editorial panel, will be published as a discussion in a future issue of the journal. 